\title{
VERBA MEMUKUL DALAM BAHASA BALI KAJIAN METABAHASA SEMANTIK
}

\author{
I Made Dian Saputra \\ Prodi Pendidikan Bahasa Bali, \\ Jurusan Pendidikan Bahasa dan Sastra Agama, Fakultas Dharma Acarya \\ Institut Hindu Dharma Negeri, Denpasar \\ Jalan Ratna no. 51, Tonja, Denpasar Utara, Kota Denpasar, Bali 80237 \\ Email: dektonk85@yahoo.com
}

\begin{abstract}
Balinese language as Balinese Lingua franca still has rules in speaking. There many Balinese words that are not familiar even neglected in this era, one of those is verb. There are many verbs in Balinese, but researcher just wants to focus on one verb, that is ngetok seen from metalanguagenatural semantics. The verb ngetok has 32 similar meanings as follows; "ngebug, ngedig, nigtig, ngupek, magambel, mugpugin, mukpukin, ngukul, nungting, ngempug, nyakcak, noktok, ngeplokin, nebuk, ngaasin, nepung, ngintuk, ngalocok, namplak, nyemés, nempéléng, nyagur, nyepédin, nglamet, ngamplongin, ngamplengin, ngemplangin, nglentangin, ngaplekin, nyontok, nylimed and mentil." From the whole verb forms of "ngetok" there are differences of each form seen from the wat of hitting related to the device used to hit, subject and object being hit. Verb in Balinese has to different meanings, that can be explained by explication technique of $X$ does something on $Y$, something good or bad happens on $Y$. The difference of meaning was gained from the analysis of original meaning with uncomposed polysemi.
\end{abstract}

Keywords: Verb Spanking “Ngetok”, dialect, Natural Semantic Metabahasa

\begin{abstract}
ABSTRAK
Bahasa Bali sebagai bahasa keseharian masyarakat yang masih tetap memperhatikan tatanan dalam berbicara. Hal ini terlihat dari masih banyak ditemukan penggunaan kata-kata dalam Bahasa Bali yang pada era modern ini sudah mulai terabaikan. Bahkan tidak jarang masyarakat tidak tahu tentang bahasa tersebut, salah satunya adalah verba. Banyak jenis verba yang ada dalam Bahasa Bali, namun peneliti tertarik pada satu verba yaitu verba memukul "ngetok" dalam Bahasa Bali yang dikaji menggunakan teori Metabahasa Semantik Alami (MSA). Verba memukul "ngetok" memiliki 32 bentuk padanan yaitu sebagai berikut "ngebug, ngedig, nigtig, ngupek, magambel, mugpugin, mukpukin, ngukul, nungting, ngempug, nyakcak, noktok, ngeplokin, nebuk, ngaasin, nepung, ngintuk, ngalocok, namplak, nyemés, nempéléng, nyagur, nyepédin, nglamet, ngamplongin, ngamplengin, ngemplangin, nglentangin, ngaplekin, nyontok, nylimed dan mentil." Dari keseluruhan bentuk verba memukul "ngetok" tersebut memiliki perbedaan masing-masing yang dilihat dari tata cara memukul berkaitan dengan alat yang digunakan memukul, subjek dan objek yang dipukul. Verba memukul "ngetok" dalam bahasa Bali memiliki dua makna berbeda yaitu melakukan dan terjadi, dapat dijelaskan dengan teknik eksplikasi " $\mathrm{X}$ melakukan sesuatu pada Y", sesuatu yang baik/buruk terjadi pada Y". Perbedaan makna ini diperoleh dari analisis makna asali dengan polisemi takkomposisi.
\end{abstract}

Kata kunci : Verba Memukul "Ngetok”, dialek, Metabahasa Semantik Alami 


\section{PENDAHULUAN}

Dalam perkembangan jaman modern saat ini banyak masyarakat terutama di kalangan anak muda yang kurang memahami dan memperhatikan tentang nilai rasa dalam berbicara. Nilai rasa perlu diperhatikan dalam berbicara agar tujuan dari komunikasi tersebut dapat tercapai. Berbicara tentang nilai rasa yang berkaitan dengan tata cara berbicara yang tentunya harus memperhatikan dengan siapa berbicara (lawan bicara), tempat dan waktu berbicara, tema pembicaraan, serta tujuan dari berbicara. Jika dikaitkan dengan verba memukul dalam Bahasa Bali hal tersebut sangat penting untuk diperhatikan.

Dilihat dari aspek linguistik setiap bahasa memiliki bentuk, fungsi dan makna yang dapat dikaji dengan analisis makna asali semantik alami. Berdasarkan analisis makna asali ini diharapkan dapat memberikan gambaran mengenai keberadaan bahasa yang memiliki perbedaan bentuk, namun masih berada dalam satu medan makna. Sejauh penelusuran penulis sudah ada beberapa penelitian tentang verba Bahasa Bali seperti verba "memotong" (ngetep) dan verba "masare-majujuk". Namun belum ada yang meneliti tentang verba memukul Bahasa Bali. Mengingat perbedaan pada masing-masing padanan verba memukul yang ada di Desa Taro perlu dianalisis maka penulis melakukan penelitian yang berjudul "Verba Memukul dalam Bahasa Bali Kajian Metabahasa Semantik Alami”.

Berdasarkan latarbelakang di atas diperoleh dua rumusan masalah yaitu:

1. Bagaimana bentuk verba memukul dalam Bahasa Bali kajian metabahasa semantik alami ?

2. Bagaimana makna verba memukul dalam Bahasa Bali kajian metabahasa semantik alami?

Dalam sebuah penelitian diperlukan adanya teori sebagai pisau bedah yang digunakan untuk membahas permasalahan penelitian. Dalam penelitian ini digunakan teori Metabahasa Semantik Alami (MSA) yang berkaitan dengan makna asali dan polisemi takkomposisi. MSA yang dipelopori oleh Anna Weir- zbicka, dkk menyatakan bahwa teori ini dapat memberikan gambaran tentang fitur-fitur semantik dan ciri khas pada masing-masing bentuk (leksikon). Terkait dengan hal tersebut Goddard (Sudipa, 2004: 146) menjelaskan bahwa "fitur semantik khusus yang disebut subtle difference melekat pada beberapa leksikon telah membentuk konfigurasi makna pembeda antara leksikon satu dengan yang lainnya, terutama pada leksikon yang berada dalam medan makna yang sama." MSA digunakan untuk mengkaji permasalah mengenai bentuk dan makna verba memukul "ngetok" dalam Bahasa Bali.

\section{METODE}

Tulisan ini merupakan hasil dari penelitian kualitatif dengan pendekatan fenomenologi yang disesuaikan dengan fenomena atau keadaan masyarakat Bali. Jenis data yang diperoleh dalam penelitian ini adalah jenis data kualitatif yang berupa pendeskripsian maupun penggambaran objek penelitian menggunakan kata-kata tanpa angka. Sumber data dibagi menjadi dua yaitu data utama dan data pelengkap. Data utama diperoleh dari hasil observasi dan wawancara yang dilakukan dengan sejumlah masyarakat yang ditentukan dengan teknik random sampling. Data pelengkap diperoleh dari sejumlah buku maupun referensi lainnya yang terkait dengan penelitian yang dilakukan.

Metode pengumpulan data dalam penelitian ini dilakukan dengan lima cara. Data diperoleh dari hasil observasi pengamatan langsung pada objek penelitian dengan teknik mencatat dan dokumentasi. Wawancara menggunakan teknik campuran dengan penentuan informan dengan teknik random sampling. Serta menggunakan metode reflektif introspektif dalam hal ini peneliti mengambil dua peran sekaligus yaitu sebagai subjek dan objek penelitian. Dalam metode reflektif introspektif ini, hasil pemikiran, pengetahuan dan nalar peneliti sebagai penutur asli bahasa yang diteliti dapat dijadikan sumber data. Selain itu data sekunder dalam penelitian ini diperoleh dari studi kepustakaan dan dokumen. 
Metode analisis data yang digunakan dalam penelitian ini meliputi reduksi data, penyajian data dan penyimpulan data. $\mathrm{Mu}-$ hammad (2011: 233) "Metode analisis data adalah cara menguraikan dan mengelompokkan satuan lingual sesuai dengan pola-pola, tema-tema, kategori-kategori, kaidah-kaidah dan masalah-masalah penelitian". Dari hasil analisis data tersebut akan dijelaskan secara deskriptif kualitatif.

\section{HASIL DAN PEMBAHASAN}

Bentuk Verba Memukul dalam Bahasa Bali Kajian Metabahasa Semantik Alami

Bentuk dari verba memukul dalam Bahasa Bali masih banyak dapat ditemukan. Hal ini dikarenakan masyarakat masih menggunakan Bahasa Bali sebagai bahasa keseharian. Bentuk verba memukul Bahasa Bali yang dianalisis menggunakan teori Metabahasa Semantik Alami (MSA). Goddard (Sudipa, 2004: 146) menjelaskan bahwa masingmasing bentuk kata memiliki fitur semantik yang dapat memunculkan makna pembeda terutama pada kata yang berada dalam satu medan makna. Demikian pula pendapat dari Anna Weirzbicka, dkk (Sudipa, 2004: 146) yang menyatakan bahwa teori MSA dapat memberikan gambaran tentang fitur-fitur semantik dengan keunikan pada masing-masing bentuk kata.

Bentuk verba memukul dalam Bahasa Bali yang diperoleh sebanyak 32 bentuk yaitu sebagai berikut "ngebug, ngedig, nigtig, ngupek, magambel, mugpugin, mukpukin, ngukul, nungting, ngempug, nyakcak, noktok, ngeplokin, nebuk, ngaasin, nepung, ngintuk, ngalocok, namplak, nyemés, nempéléng, nyagur, nyepédin, nglamet, ngamplongin, ngamplengin, ngemplangin, nglentangin, ngaplekin, nyontok, nylimed dan mentil." Padanan dari verba memukul Bahasa Bali tersebut memiliki perbedaan masing-masing yang dapat dilihat dari cara memukul yang berkaitan dengan alat yang digunakan memukul, pelaku (subjek) dan penderita (objek). Hal tersebut akan dijelaskan sebagai berikut :

\section{Tata Cara Memukul}

Tata cara memukul yang berkaitan dengan alat yang digunakan untuk memukul, subjek dan objek yang dipukul.

\section{a. Ngebug}

Kata ngebug sering dikaitkan dengan orang yang sedang memainkan alat musik berupa gambelan (magambel). Penggunaan kata ngebug dapat dilihat pada kalimat berikut:

(01) Gebugin malu gongé pang énggal tawang pelihné.

Pada kalimat (01) menyatakan ngebugin gong. Kata ngebug sering diucapkan apabila objek yang dipukul berupa gong dan kempur. Saat alat musik ini dipukul akan menghasilkan suara yang bergema. Alat yang digunakan untuk memukul disebut panggul dengan cara memukul agak pelan dari samping.

\section{b. Ngedig}

Kata ngedig juga sering dikaitkan dengan cara memukul objek berupa alat musik gambelan seperti kendang, gender dan gangsa seperti pada contoh kalimat (02). Alat yang digunakan memukul berupa panggul dengan cara memukul agak cepat dan keras sehingga menimbulkan suara yang nyaring.

(02) Kendangé lantas gedigin, mara ngedig gendér paling siduri pang nyak maadungan.

Selain diucapkan saat memainkan alat musik kata ngedig juga diucapkan saat memukul pentungan (kukul). Seperti contoh dibawah ini:

(03) Krama sareng sami tunas titiang benjang idadané mangda ngayah mareresik ring Pura Taman Béji, galah pitu semeng sampun gedig kulkul.

Pada kalimat tersebut dikatakan ngedig kulkul. Dilihat dari alat yang digunakan memukul berupa kayu (panggul) berbeda dengan panggul untuk ngedig gambelan. Berdasarkan kedua pernyataan tersebut dapat disimpulkan bahwa kata ngedig dilakukan menggunakan alat yang disebut panggul dengan cara memukul agak cepat berulang-ulang dengan permukaan objek agak lebar dan datar. 


\section{c. Nigtig}

Nigtig dilakukan dengan cara memukul berulang-ulang menggunakan alat seperti kayu, lidi atau sapu. Seperti contoh beberapa kalimat berikut :

(04) Sing buungan Méméné nigtig panakné sawiréh bes kalu.

Kalimat (04) menyatakan nigtig panak. Kata nigtig panak berkaitan dengan kondisi emosi. Apabila orang yang sedang marah memukul orang lain dengan sapu atau kayu dilakukan secara berulang-ulang pada bagian belakang tubuh yaitu pada pinggang sampai pantat disebut nigtig. Berbeda dengan kalimat (04) yang menyatakan nigtig dilakukan pada badan manusia. Kata nigtig juga sering diucapkan untuk kata nigtig kasur dan nigtig ember.

(05) Dé, tigtigin jep kasuré ané majemuh pang ilang bukné.

(06) Telanan nigtig émbér, empeng kupingé medigang.

Kalimat (05) menyatakan tigtigin kasuré dan kalimat (06) menyatakan nigtig ember. Pada kedua kalimat tersebut menyatakan objek yang dipukul berupa benda tempat tidur dan ember. Nigtig kasur yang bertujuan membersihkan kasur menggunakan sapu lidi. Dan nigtig ember biasanya dilakukan oleh anak-anak yang sedang bermain. Berdasarkan beberapa penjelasan diatas kata nigtig merupakan kata memukul yang dilakukan dengan berulang-ulang menggunakan alat seperti kayu dan sapu dengan permukaan objek yang agak luas.

\section{d. Ngupek}

Ngupek berkaitan dengan orang yang memainkan alat musik gambelan seperti kendang. Ngupek dilakukan menggunakan telapak tangan tanpa menggunakan alat. Cara ngupek dilakukan dari samping yang objeknya hanya berupa kendang. Saat melihat orang ngupek biasanya muncul pernyataan seperti pada kalimat berikut :

(07) Lemuh pesan liman tukang kendangé ngupek kendang.

\section{e. Magambel}

Kata magambel berkaitan dengan objek berupa seperangkat gambelan. Gambelan yang dimaksud berupa kendang, gender, cengceng, gangsa, kempur, dan lainnya yang dipukul bersamaan oleh sekelompok orang berdasarkan guru ding dong. Alat yang digunakan megambel berupa panggul dengan bentuk yang berbeda-beda. Subjeknya adalah orang dengan objek berupa seperangkat gambelan. Seperti kalimat berikut:

(08) Odalané suba paek, sekeha gong cerik-ceriké seleg pesan mauruk magambel.

\section{f. Mugpugin}

Kata mugpugin sering diucapkan saat ada perkelahian antara dua orang atau lebih yang dilakukan secara berulang-ulang.

(09) Anak cerik ento mugpugin méméné sawiréh tusing baanga meli plalianan.

(10) Truna-trunané jani liu ané demen mugpugin timpal ngaé mamusuh.

Pada kalimat (09) dikatakan mugpugin méméné (memukuli ibunya) dapat dilihat objek adalah ibu dan subjek adalah anak. Mugpugin dilakukan menggunakan tangan mengepal dengan arah memukul dari belakang yang difokuskan pada pinggang maupun badan bagian belakang. Tidak jauh berbeda pada kalimat (10) dikatakan memukul temannya (mugpugin timpal) objek, subjek serta cara melakukan hampir sama dengan mugpugin méméné. Berdasarkan hal tersebut mugpugin adalah memukul yang dilakukan berulang-ulang dengan tangan dikepal dengan cara memukul dari belakang biasanya pada saat bertengkar kondisi marah.

\section{g. Mukpukin}

Kata mukpukin diucapkan hanya pada buah-buahan saja seperti buah nangka dan semangka. Mukpukin bertujuan agar mengetahui kematangan dari buah. Cara melakukannya adalah menggunakan telapak tangan yang langsung dipukulkan pada bagian buah, dengan gerakan dari atas ke bawah.

\section{h. Ngukul}

Ngukul diidentikkan dengan acara di masyarakat. Apabila sudah terdengar su- 
ara pentongan (kulkul) masyarakat dengan segera menuju balai pertemuan. Ngukul dibedakan menjadi empat bagian berdasarkan jumlah pukulannya (tuludan) yaitu : jika terdengar sekali pukulan pertanda ada orang menikah, tiga kali pukulan pertanda berduka ada masyarakat yang meninggal, berkali-kali dengan dengan suara beraturan pertanda ada untuk mengumpulkan masyarakat di Banjar dan jika terdengar suara pukulan berkali-kali, keras dan tidak beraturan disebut kulkul bulus pertanda ada mara bahaya di desa. Ngukul biasanya dilakukan oleh masyarakat yang sudah terpilih dan memiliki kedudukan di masyarakat. Ngukul tidak dilakukan oleh sembarang orang karena kulkul di Bali disakralkan. Ngukul dilakukan menggunakan panggul yang terbuat dari kayu, objeknya berupa pentungan (kulkul) dengan cara memukul berulang-ulang sesuai dengan tujuan ngukul tersebut. Penggunaan kata ngukul dapat dilihat pada contoh berikut : tuni ngukul!

(11) Énggalin ka Pura Jero Mangku ba

(12) Jero Bendésa ba kel ka jeroan ngukul, énggalin dik manjus.

(13) Mai énggalin ka balé banjaré nak ba ngukul.

\section{i. Nungting}

Kata nungting sering diucapkan oleh seorang pemuka adat saat upacara keagamaan di pura untuk mengarahkan petugas (saya) untuk nungting. Nungting disebut nyuarang pejenengan (kulkul). Cara memukul mirip dengan ngukul namun objeknya berupa dua buah kulkul yang dipukul secara bergantian. Biasanya nungting dilakukan pada saat Ida Bhatara medal atau diturunkan dari tempatnya dipuja. Nungting berkaitan dengan hal yang sifatnya lebih sakral. Penggunaan kata nungting dapat dilihat pada kalimat berikut:

(14) Majeng Jero saya mangda gelis nungting duaning Ida Bhatara jagi medal.

\section{j. Ngempug}

Kata ngempug berarti membuka sesuatu dengan cara memukul. Dalam hal ini objek yang dipukul masih utuh. Ngempug biasanya diucapkan saat seseorang sebagai subjek memukul objek berupa kayu yang besar menggunakan alat tajam yang disebut kapak (kandik). Objek diletakkan di bawah kemudian dipukul atau dibelah sampai ukurannya kecil-kecil. Penggunaan kata ngempug seperti kalimat berikut :

(15) Binmani semengan tulungin jep ngempug saang ditegalé daja.

\section{k. Nyakcak}

Nyakcak dilakukan dengan cara memukul berulang-ulang dari atas ke bawah objek berupa jahe, sirih maupun bahan rempah lainnya untuk bahan obat. Nyakcak dilakukan dengan alat berupa batu borehan. Objek dipukul-pukul sampai lumat dan halus.

(16) I dadong nyakcak jahé lakar boréh nganggon batu boréhan.

(17) Suud nyakcak jahé umbah malu batu boréhané suud to mara nyakcak basé.

\section{l. Noktok}

Noktok berkaitan dengan orang memahat atau orang membuat patung dari kayu. Noktok dilakukan menggunakan alat berupa alat pemahat peet dan pengotok. Noktok dilakukan dengan memukul-mukul peet menggunakan pengotok dari atas ke bawah. Subjek melakukan noktok dengan posisi duduk objek berupa kayu diletakkan di depannya.

(18) Kanti bungker tunduné Pak Wayan sabilang wai noktok kayu.

\section{m. Ngeplokin}

Ngeplokin dilakukan dengan cara memukul berulang-ulang menggunakan alat seperti palu. Subjek berupa orang dan objek berupa benda berupa buah kelapa yang sudah dikupas serabutnya. Kelapa diletakkan di tangan kemudian dipukul menggunakan palu sampai kelapa pecah. Dilakukan dengan gerakan agak cepat dan keras dari atas ke bawah. Berbeda dengan hal tersebut ada yang mengatakan memukul anjing (ngeplokin cicing) dan ngeplokin malinge objeknya berupa hewan dan manusia. Alat yang digunakan sama yaitu berupa palu, dengan cara memukul dari bagian belakang objek. 


\section{n. Nebuk, ngaasin, nepung, ngintuk dan ngelocok}

Bentuk dari kata memukul tersebut dilakukan dengan cara memukul berulang-ulang menggunakan alat berupa alu dan lesung dengan gerakan dari atas ke bawah. peralatan yang digunakan hampir sama namun hasilnya berbeda. Nebuk yang objeknya berupa padi atau buah kopi kering yang ditumbuk sampai terlepas kulit luarnya. Ngaasin menggunakan alu dan lesung terbuat dari kayu dengan objek berupa padi yang baru dipanen dan kering, hasilnya padi yang masih berkulit untuk melepaskan dari tangkai padi. Nepung menggunakan alu dan lesung terbuat dari batu objeknya berupa beras yang masih agak basah yang ditumbuk sampai menjadi tepung. Ngintuk objeknya berupa daging atau bahan bumbu ditumbuk sampai lumat dan ngalocok menggunakan alu dan lesung, objeknya berupa buah kopi yang baru dipetik, ditumbuk sampai terkelupas kulitnya kemudian dijemur.

\section{o. Namplak dan nyemes}

Namplak dilakukan menggunakan telapak tangan. Namplak biasanya diucapkan untuk memukul nyamuk, lalat ataupun memukul badan kita sendiri. Namplak legu, namplak buyung, namplak gidat. Dilihat dari objek, ukuran objek cenderung lebih kecil dari subjeknya. Pada bagian tubuh manusia namplak tidak hanya di bagian kepala saja melainkan di seluruh bagian badan dapat dikatakan namplak, biasanya bagian wajah, tangan, kaki, pundak. Nyemes berkaitan dengan permainan bola voli. Nyemes merupakan bahasa serapan dari bahasa asing yang penggunaannya sering kita dengar saat permainan bola voli. Nyemes dilakukan dengan telapak tangan objek berupa bola voli.

(19) Tusing dadi gigisan namplak pipin panakné kanti balan.

\section{p. Nempeleng}

Nempeleng yaitu memukul dilakukan menggunakan tangan dari samping. Objek berupa pelipis.
Nyagur dilakukan menggunakan tangan yang dikepalkan, biasanya saat ada perkelahian, objek di bagian wajah.

\section{r. Nyepedin, Nglamet dan Ngamplongin}

Kata-kata tersebut di atas memiliki sedikit persamaan dalam cara melakukannya dan perbedaannya dapat dilihat dari ukuran alat yang digunakan. Nyepedin biasanya menggunakan alat seperti pecut, lidi atau kayu yang berukuran agak kecil dengan cara memukul hanya sekali objek badan. Nglamet menggunakan alat seperti kayu, bambu yang ukurannya lebih besar dari nyepedin. Ngamplongin menggunakan kayu atau bambu yang berukuran agak besar. Ngamplongin biasanya dilakukan di kepala.

\section{s. Ngamplengin, Ngemplangin, Nglentangin dan Nyontok}

Kata-kata tersebut merupakan kata memukul yang dilakukan pada bagian kepala. Perbedaannya terletak pada tata cara dan arah memukul. Ngamplengin dengan cara memukul dari samping menggunakan telapak tangan. Ngemplangin dilakukan menggunakan telapak tangan menghadap ke bawah dengan arah memukul dari atas ke bawah pada bagian atas kepala. Nglentangin dilakukan dengan cara jari tangan sedikit ditekuk, bagian ujungnya digunakan memukul pada bagian atas kepala dengan agak keras. Nyontok posisi tangan sama dengan nglentangin, namun dilakukan pada dahi. Jari yang ditekuk dipukulkan pada dahi agak menempel sedikit ditekan.

\section{t. Ngaplekin dan Nylimed}

Ngaplekin dilakukan menggunakan tangan dengan arah pukulan dari belakang objek. Nylimed menggunakan kain sesuatu yang lembut, dipukulkan dari belakang objek.

\section{u. Mentil}

Mentil dilakukan menggunakan jari tangan. Telunjuk dan ibu jari disatukan kemudian jari dilepas, objeknya pada seluruh bagian tubuh.

\section{q. Nyagur}


Makna Verba Memukul dalam Bahasa Bali Kajian Metabahasa Semantik Alami

Makna pada masing-masing verba diperoleh dari penggabungan makna asali dan polisemi takkomposisi yang dijelaskan dengan teknik eksplikasi. Verba memukul memiliki dua makna berbeda yaitu melakukan dan terjadi. Pada penjelasan berikut bentuk verba diklasifikasikan berdasarkan pada menggunakan dan tidak menggunakan alat.

\section{a. Makna Verba Memukul Menggunakan} Alat

\section{Ngebug, Ngedig, Ngukul, Nungting}

Pemetaan komponennya "X (subjek) melakukan sesuatu pada Y (objek)" menggunakan alat (panggul) dengan cara memukul berulang-ulang, "Y menghasilkan bunyi”. Dapat dieksplikasikan sebagai berikut :

Pada saat bersamaan, $\mathrm{X}$ melakukan sesuatu pada Y. Karena itu, sesuatu terjadi pada Y, X melakukan menggunakan alat berupa panggul, $\mathrm{X}$ melakukan dengan berulangulang, $\mathrm{X}$ merasakan senang, $\mathrm{X}$ menghasilkan suara, $\mathrm{X}$ menginginkan ini, $\mathrm{X}$ melakukan ini.

\section{Nebuk, Ngaasin, Nepung, Ngintuk, Nga- locok}

Pemetaan komponennya "X (subjek) melakukan sesuatu pada Y (objek)" menggunakan alat (alu dan lesung) dengan cara memukul berulang-ulang dari atas ke bawah. Dapat dieksplikasikan sebagai berikut :

Pada saat bersamaan, $\mathrm{X}$ melakukan sesuatu pada Y. Karena itu, sesuatu terjadi pada Y, X melakukan menggunakan alu dan lesung, $\mathrm{X}$ melakukan dengan berulang-ulang dari atas ke bawah, $\mathrm{X}$ sedang senang, $\mathrm{X}$ menginginkan ini, X melakukan sesuatu seperti ini.

\section{Noktok}

Pemetaan komponennya "X (subjek) melakukan sesuatu pada Y (objek)" menggunakan alat (peet dan pengotok) dengan cara memukul berulang-ulang dari atas ke bawah. Dapat dieksplikasikan sebagai berikut :

Pada saat bersamaan, $\mathrm{X}$ melakukan sesuatu pada Y. Karena itu, sesuatu terjadi pada Y, X melakukan menggunakan peet dan pengotok, X melakukan dengan berulang-ulang dari atas ke bawah, $\mathrm{X}$ menginginkan ini, $\mathrm{X}$ melakukan sesuatu seperti ini.

\section{Ngempug, Ngeplokin}

Pemetaan komponennya " $\mathrm{X}$ (subjek) melakukan sesuatu pada Y (objek)" menggunakan alat (palu dan kapak) dengan cara memukul berulang-ulang dari atas ke bawah. Dapat dieksplikasikan sebagai berikut :

Pada saat bersamaan, $\mathrm{X}$ melakukan sesuatu pada Y. Karena itu, sesuatu terjadi pada Y, X melakukan menggunakan palu dan kapak, X melakukan dengan berulang-ulang dari atas ke bawah, $\mathrm{X}$ menginginkan ini, $\mathrm{X}$ melakukan sesuatu seperti ini.

\section{Nigtig}

Pemetaan komponennya "X (subjek) melakukan sesuatu pada Y (objek)" menggunakan alat (kayu) dengan cara memukul berulang-ulang pada bagian belakang badan. Dapat dieksplikasikan sebagai berikut :

Pada saat bersamaan, $\mathrm{X}$ melakukan sesuatu pada Y. Karena itu, sesuatu terjadi pada Y, X melakukan menggunakan kayu, X melakukan dengan berulang-ulang pada bagian belakang badan, X sedang emosi, X menginginkan ini, X melakukan sesuatu seperti ini.

\section{Nyepédin, Nglamet, Ngamplongin}

Pemetaan komponennya "X (subjek) melakukan sesuatu pada Y (objek)" menggunakan alat (kayu, bambu) dengan cara memukul sekali pada bagian belakang badan. Dapat dieksplikasikan sebagai berikut :

Pada saat bersamaan, $\mathrm{X}$ melakukan sesuatu pada Y. Karena itu, sesuatu terjadi pada Y, X melakukan menggunakan kayu atau bambu, X melakukan sekali pada bagian belakang badan, X sedang emosi, X menginginkan ini, X Melakukan sesuatu seperti ini.

\section{Nylimed}

Pemetaan komponennya " $\mathrm{X}$ (subjek) melakukan sesuatu pada Y (objek)" menggunakan alat (kain) dengan cara memukul sekali pada bagian belakang badan. Dapat dieksp- 
likasikan sebagai berikut :

Pada saat bersamaan, $\mathrm{X}$ melakukan sesuatu pada Y. Karena itu, sesuatu terjadi pada $\mathrm{Y}, \mathrm{X}$ melakukan menggunakan kain, $\mathrm{X}$ melakukan sekali pada bagian belakang badan, X menginginkan ini, X melakukan sesuatu seperti ini.

\section{Magambel}

Pemetaan komponennya " $\mathrm{X}$ (subjek) melakukan sesuatu pada Y (objek)" menggunakan alat (panggul) dengan cara memukul berulang-ulang pada objek berupa gambelan. Dapat dieksplikasikan sebagai berikut :

Pada saat bersamaan, X melakukan sesuatu pada Y. Karena itu, sesuatu terjadi pada Y, Y berupa gambelan, $\mathrm{X}$ melakukan menggunakan panggul, $\mathrm{X}$ melakukan berulang-ulang, $\mathrm{X}$ menginginkan ini, $\mathrm{X}$ melakukan sesuatu seperti ini.

\section{b. Makna Verba Memukul Tanpa Alat}

\section{Mukpukin}

Pemetaan komponennya " $\mathrm{X}$ (subjek) melakukan sesuatu pada Y (objek)" menggunakan telapak tangan dengan cara memukul berulang-ulang pada objek berupa buah nangka. Dapat dieksplikasikan sebagai berikut :

Pada saat bersamaan, X melakukan sesuatu pada Y. Karena itu, sesuatu terjadi pada $\mathrm{Y}, \mathrm{Y}$ berupa buah nangka, $\mathrm{X}$ melakukan menggunakan telapak tangan, $\mathrm{X}$ melakukan berulang-ulang, $\mathrm{X}$ menginginkan ini, $\mathrm{X}$ melakukan sesuatu seperti ini.

\section{Mugpugin}

Pemetaan komponennya " $\mathrm{X}$ (subjek) melakukan sesuatu pada Y (objek)" menggunakan tangan dikepalkan dengan cara memukul berulang-ulang pada objek berupa badan manusia. Dapat dieksplikasikan sebagai berikut :

Pada saat bersamaan, $\mathrm{X}$ melakukan sesuatu pada Y. Karena itu, sesuatu terjadi pada Y, Y berupa badan manusia, X melakukan menggunakan telapak tangan, $\mathrm{X}$ melakukan berulang-ulang, $\mathrm{X}$ dalam keadaan emosi,
$\mathrm{X}$ menginginkan ini, $\mathrm{X}$ melakukan sesuatu seperti ini.

\section{Namplak, Nyemés}

Pemetaan komponennya " $\mathrm{X}$ (subjek) melakukan sesuatu pada Y (objek)" menggunakan telapak tangan dengan cara memukul sekali pada objek berupa bola voli. Dapat dieksplikasikan sebagai berikut :

Pada saat bersamaan, $\mathrm{X}$ melakukan sesuatu pada Y. Karena itu, sesuatu terjadi pada Y, Y berupa bola voli, X melakukan menggunakan telapak tangan, $\mathrm{X}$ melakukan sekali, $\mathrm{X}$ menginginkan ini, $\mathrm{X}$ melakukan sesuatu seperti ini.

\section{Nyagur}

Pemetaan komponennya " $\mathrm{X}$ (subjek) melakukan sesuatu pada Y (objek)" menggunakan tangan dikepalkan dengan cara memukul sekali pada objek bagian wajah. Dapat dieksplikasikan sebagai berikut :

Pada saat bersamaan, $\mathrm{X}$ melakukan sesuatu pada Y. Karena itu, sesuatu terjadi pada Y, Y bagian wajah, X melakukan menggunakan tangan dikepalkan, $\mathrm{X}$ melakukan sekali, X menginginkan ini, X melakukan sesuatu seperti ini.

\section{Nempéléng}

Pemetaan komponennya " $\mathrm{X}$ (subjek) melakukan sesuatu pada Y (objek)" menggunakan telapak tangan dengan cara memukul sekali dari samping pada bagian wajah. Dapat dieksplikasikan sebagai berikut:

Pada saat bersamaan, $\mathrm{X}$ melakukan sesuatu pada Y. Karena itu, sesuatu terjadi pada $\mathrm{Y}$, Y pelipis bagian wajah, $\mathrm{X}$ melakukan menggunakan telapak tangan, $\mathrm{X}$ melakukan sekali, X menginginkan ini, X melakukan sesuatu seperti ini.

\section{Ngamplengin, Ngemplangin, Nglentangin, Nyontok}

Pemetaan komponennya " $\mathrm{X}$ (subjek) melakukan sesuatu pada Y (objek)" menggunakan telapak tangan dengan cara memukul sekali pada bagian kepala. Dapat dieksplikasikan sebagai berikut : 
Pada saat bersamaan, $\mathrm{X}$ melakukan sesuatu pada Y. Karena itu, sesuatu terjadi pada Y, Y pelipis bagian wajah, $\mathrm{X}$ melakukan menggunakan telapak tangan, $\mathrm{X}$ melakukan sekali, $\mathrm{X}$ menginginkan ini, $\mathrm{X}$ melakukan sesuatu seperti ini.

\section{Ngaplekin}

Pemetaan komponennya " $\mathrm{X}$ (subjek) melakukan sesuatu pada Y (objek)” menggunakan telapak tangan dengan cara memukul sekali pada bagian punggung, pundak, kepala. Dapat dieksplikasikan sebagai berikut :

Pada saat bersamaan, $\mathrm{X}$ melakukan sesuatu pada Y. Karena itu, sesuatu terjadi pada Y, Y punggung, pundak, kepala bagian atas, $\mathrm{X}$ melakukan menggunakan telapak tangan, $\mathrm{X}$ melakukan sekali, $\mathrm{X}$ menginginkan ini, X melakukan sesuatu seperti ini.

\section{Mentil}

Pemetaan komponennya " $\mathrm{X}$ (subjek) melakukan sesuatu pada Y (objek)" menggunakan telunjuk dan ibu jari tangan dengan cara memukul sekali pada seluruh bagian badan. Dapat dieksplikasikan sebagai berikut :

Pada saat bersamaan, X melakukan sesuatu pada Y. Karena itu, sesuatu terjadi pada Y, Y seluruh bagian badan, $\mathrm{X}$ melakukan menggunakan telunjuk dan ibu jari tangan, $\mathrm{X}$ melakukan sekali, $\mathrm{X}$ menginginkan ini, $\mathrm{X}$ melakukan sesuatu seperti ini.

\section{Ngupek}

Pemetaan komponennya " $\mathrm{X}$ (subjek) melakukan sesuatu pada Y (objek)" menggunakan telapak tangan dengan cara memukul berulang-ulang dari samping. Dapat dieksplikasikan sebagai berikut :

Pada saat bersamaan, X melakukan sesuatu pada Y. Karena itu, sesuatu terjadi pada Y, Y berupa kendang, X melakukan menggunakan telapak tangan, $\mathrm{X}$ melakukan sekali, X menginginkan ini, X Melakukan sesuatu seperti ini.

\section{PENUTUP}

\section{Simpulan}

Pada masing-masing bentuk dari verba memukul dalam Bahasa Bali memiliki perbedaan yang dapat dilihat dari tata cara memukul yang berkaitan dengan alat yang digunakan, subjek dan objek memukul.

Makna dari verba memukul memiliki dua makna yang berbeda yaitu melakukan dan terjadi. Pelaku sebagai (subjek) melakukan sesuatu terhadap penderita (objek) sehingga sesuatu terjadi pada objek.

\section{DAFTAR PUSTAKA}

Anonim. 2006. Tata Basa Bali. Gianyar: Dinas Kebudayaan Kabupaten Gianyar.

Anonim. 2016. Profil Desa Taro. Gianyar: Kantor Desa Taro.

Arikunto, S. 1997. Prosedur Penelitian Suatu Pendekatan Praktik. Jakarta: Rineka Cipta.

Astuti, N. W. 2015. Klausa Dialek Bali Aga Desa Pakraman Selulung Kecamatan Kintamani Kabupaten Bangli (Kajian Sintaksis). Skripsi, 19.

Djajasudarma, F. 2013. Fonologi \& Gramatikal Sunda. Bandung: PT Refika Aditama.

Gande, V. 2012. Verba "Memotong" dalam Bahasa Manggarai. Seminar Nasional dalam rangka Hari Bahasa Ibu Internasional. Denpasar: Unpubliser.

Herma. 2012, 06 minggu. google. Retrieved 11 minggu, 2015, from hermabastra09.blogs pot.com: http// google.com

Manda, I. N. 2013. Widia Sari Basa lan Sastra Bali. Denpasar.

Muhammad, M. 2011. Metode Penelitian Bahasa. Jogjakarta: Ar- Ruzz Media.

Mulyadi. (nt). Verba Emosi Statif dalam Bahasa Melayu Asahan. Sumatra Utara: unpubliser.

Sobur, A. 2003. Semiotika Komunikasi. Bandung: PT. Remaja Rosdakarya.

Sudikan, S. Y. 2001. Metode Penelitian Sastra Lisan. Surabaya: Citra Wacana.

Sudipa, I. N. 2004. Makna 'Bawa' dalam Bahasa Bali: Tinjauan Metabahasa Semantik Alami. Wibawa Bahasa Untuk Prof.Dr. 
I Wayan Bawa, 146-152

2005. NSM Dalam Bahasa Bali. Cemetuk Untuk Prof. H T A Ridwan, Ph.D.

2010. Struktur Semantik Verba Keadaan Bahasa Bali. Denpasar: Udayana University Press.

2010. Struktur Semantik Verba Bahasa

Bali “Mesare Majujuk". Seminar Interna-

sional Bahasa Bali dan Budaya Austronesia V, (pp. 1-13). Denpasar.

Sugiyono. 2011. Metode Penelitian. Bandung: Alpabeta.

Widiantana, I. K. 2012. Aksara Wreastra dan Modre dalam Aksara Bali (Studi Struktur Makna dan Nilai Sosioreligius dalam Agama Hindu). Denpasar: Unpubliser. 